OPEN ACCESS

Edited by:

Hiba Baroud,

Vanderbilt University, United States

Reviewed by:

Joseph Tomain,

University of Cincinnati, United States

Tracy Hester,

University of Houston, United States

${ }^{*}$ Correspondence:

Robert R. M. Verchick

verchick@loyno.edu

†These authors have contributed equally to this work and share first authorship

Specialty section:

This article was submitted to

Climate Law and Policy,

a section of the journal

Frontiers in Climate

Received: 30 June 2021

Accepted: 05 October 2021

Published: 06 December 2021

Citation:

Verchick RRM and Lyster R (2021)

Building a Climate-Resilient Power

Grid: Lessons From Texas-Size

Storms and the Queensland Floods.

Front. Clim. 3:734227.

doi: $10.3389 /$ fclim.2021.734227

\section{Building a Climate-Resilient Power Grid: Lessons From Texas-Size Storms and the Queensland Floods}

\author{
Robert R. M. Verchick ${ }^{1 * \dagger}$ and Rosemary Lyster ${ }^{2+}$ \\ ${ }^{1}$ Loyola University New Orleans, College of Law, New Orleans, LA, United States, ${ }^{2}$ The University of Sydney, The University \\ of Sydney Law School, Sydney, NSW, Australia
}

When a city is lashed by storm or swamped by epic rains, there's at least one predictable moment in the chaos: the lights go out. In this article, we focus on the challenge of protecting assets from storms and floods in the era of climate breakdown. This often involves physical fortification or smarter placement. To understand the policies and decisions involved, we examine recovery efforts following storm- or flood-based outages that occurred this century in the state of Texas in the United States and the state of Queensland in Australia. We first describe the outages, their consequences, and the policy recommendations and responses that followed. We then evaluate the recovery processes, focusing on the challenge of protecting assets like substations and transmission structures. We find that each jurisdiction could do more to incorporate forward-looking climate data, to match the level of government authority to better fit the desired function, and to capably fund the work to be done.

Keywords: Australia, climate change adaptation, climate change disaster, electricity, infrastructure, United States

\section{INTRODUCTION}

When a city is lashed by storm or swamped by epic rains, there's at least one predictable moment in the chaos: the lights go out. The widespread loss of electricity-essentially a disaster within a disaster-can force a whole region to its knees. From rancid food to emergency-room nightmares, communities take a punch when the lights go out. Aging power grids leave us more susceptible to risks like these. And the growing intensity of floods and storms on account of climate change make things even worse. In earlier work, we have examined the most important elements in making a power grid more resilient to climate breakdown: protecting assets, smartening network distribution, and greening the inputs (Lyster and Verchick, 2018).

In this article, we focus on threats posed to the power grid by storms and floods-two prevalent hazards now amplified by the climate crisis. Our goal, as in our earlier work, is to identify strategies to strengthen "climate resilience," defined by the United Nations' Intergovernmental Panel on Climate Change as "the ability to cope with a climate disturbance and recover in a way that preserves one's essential character, while at the same time exercising the capacity for adaptation, learning, and growth" (Intergovernmental Panel on Climate Change IPCC, 2018, 557). "Adaptation," in this sense, describes the ability "to adjust to potential damage, to take advantage of opportunities, or to respond to consequences" (Intergovernmental Panel on Climate Change IPCC, 2018, 542). To understand the policies and decisions involved, we examine recovery efforts following storm- or flood-based outages that occurred this century in the state of Texas in 
the United States and the state of Queensland in Australia. While these states differ in various ways, they share certain characteristics that are enlightening. Namely, both are states in wealthy, industrialized countries; both exist within federal systems known to favor local land-use controls; both contain sprawling landscapes prone to coastal and riverine flooding; and both operate in electricity markets that are loosely regulated and that rely strongly on market incentives.

We first describe the outages, their consequences, and the policy recommendations and responses that followed. We then evaluate the recovery processes, focusing on the challenge of protecting assets like substations and transmission structures. We find that each jurisdiction could do more to incorporate forwardlooking climate data, to match the level of government authority to better fit the desired function, and to capably fund the work to be done.

\section{TEXAS-SIZE STORMS}

This century, Texas has been struck by intense storms, causing epic flooding in the summer and freak cold snaps in the winter. The damage has called the efficacy of the power grid into question. In 2008, Hurricane Ike hit southeastern Texas, knocking out power for more than 2 million residents in the Houston metropolitan area for up to 2.5 weeks. The main cause: tree limbs blown into power lines (Fehling, 2013). After Ike, Houston's main utility, CenterPoint Energy, significantly enhanced vegetation management along its rights of ways and installed smart meters capable of detecting and reporting on local outages (St. John, 2015).

In August 2015, Hurricane Harvey charged the Texas coast, bringing 130 mile-per-hour winds and an enormous amount of rain. In just a few days 25 trillion gallons of water fell on the south-eastern part of the state. Experts attribute 82 deaths to the storm and property damage amounting to US $\$ 125$ billion (TLBO, 2017). The storm tore through hundreds of electricity lines and flooded dozens of facilities. More than 10,000 MW of electricity capacity went offline; 300,000 customers lost power (St. John, 2015; Lott, 2017; Amadeo, 2020). CenterPoint Energy's multi-million-dollar smart grid project was no match for a storm this big, and its automated communications features proved of little use (TLBO, 2017). The storm interfered not only with electricity generation and distribution, but also with fuel production, crippling one third of U.S. oil refineries (EOS, 2018, 122).

To assess the damages from Hurricane Harvey and develop better policy, Texas governor Greg Abbott appointed a commission charged with developing a framework for reducing the risk of future disasters. The many recommendations of this comprehensive report can be reduced to two main prescriptions: (1) assess and prepare for future risks and (2) coordinate local decision making (EOS, 2018, 105). But there was a big hole: while almost every weather extremity in Texas is backlit by global warming, the 157-page report mentioned "[a] changing climate" only once (EOS, 2018, 114). Instead, the Report spoke continually of "future-proofing" the state-a concept not precisely defined but which involves "anticipating future storm events" and "minimizing their effects on lives and property" (EOS, 2018, 154). The Report never defines what data would be necessary to anticipate future storms, nor does it mention the relationship between climate change and future conditions.

To take some examples relevant to the electricity grid, the Report urges local governments to avoid siting important facilities in areas designated by the U.S. Federal Emergency Management Agency (FEMA) as "100-year flood" zones (that is, having an "annual exceedance probability," or AEP, of $1 \%$ or higher), (EOS, 2018, 108). If a local government (city or county) chooses to allow development in such areas, the Report recommends the government require a level of protection designed to protect against such inundation along with an added margin of safety, or "freeboard." To protect, "critical facilities," including those related to electricity generation and distribution, the Report acknowledges that levees or seawalls may prove an effective option (EOS, 2018, 113). It also encourages further examination of a multi-billion-dollar coastal barrier system that some have proposed as a way of protecting the greater Houston area from storm surge (EOS, 2018, 114). The Report urges facilities to voluntarily adopt hazard mitigation plans, citing the Houston Medical Center's efforts (EOS, 2018, 116).

The Report assigns many decisions to local governments, including those related to levees, construction standards, and warning systems (EOS, 2018, 112). To avoid "a patchwork of flood mitigation strategies" within the same watershed, the Report urges local governments to collaborate with one another where needed. The Report emphasizes that interventions made upstream "should never hurt downstream neighbors" (EOS, 2018, 122 , emphasis in original). For resilience projects on the coast, the Report recommends "a formal process by which the state and local jurisdictions can work together to identify and prioritize projects that will contribute to the overall goal of future-proofing the state" (EOS, 2018, 124).

More recently, in February 2021, a major cold snap-known as Winter Storm Uri-paralyzed the state, leaving as many as four million people without electricity or heating fuel in icy temperatures. Water pipelines burst, and water treatment plants failed. All told, more than a hundred people died (Sandoval et al., 2021). The main culprit was a failure in power generation related to natural gas, which supports two-thirds of the state's electricity needs. When natural gas wells and pipelines froze, normal production fell by $45 \%$, leaving many gas-fired power plants without fuel (Gimon, 2021, 4-5). Some gas-fired power plants, with their own pumps and pipes to deal with, were also immobilized (Roberts, 2021). Without evidence, some state officials and conservative news outlets blamed the mess on "ugly wind generators" (Douglas and Ramsey, 2021; quoting Sid Miller, Commissioner of Texas Department of Agriculture). In fact, wind - which makes up only $7 \%$ of the planned winter capacityperformed as well or better than expected (Aronoff, 2021). At any rate, almost none of the power-producing infrastructurefrom derricks to pipelines to wind turbines to power plants-had been equipped with adequate insulation, heating elements, or other forms of weatherization (Cooper, 2021; Hernandez et al., 2021). 
In addition to lax mandates on weatherization, Uri also focused attention on other features of Texas's power network. First, electricity in most of the state is run by a single network operator; thus, Texas effectively has its own grid that is isolated from the western and eastern grids that cover the nation's other contiguous states. This isolation frees the state's electricity market from federal oversight, something that state leaders see as an advantage. Unfortunately, an islanded grid also prevents the easy importation of electricity in times of emergency. Second, the state's electricity market works on a rather extreme model of "retail choice." This allows customers to choose between longterm contracts with steady rates or contracts "that pass along fluctuating wholesale prices for a nominal fee" (Aronoff, 2021). What is extreme is that even in emergency situations, retail rates can be allowed to climb as high as US\$9,000 per MWh. As a result, some customers received bills as high as US $\$ 10,000$ for the month during that time (Burke, 2021).

It may be too early to know what policy changes, if any, result from Uri. At the time of writing, there seems to be little appetite for mandating weatherization for power generators or further connecting the Texas grid to transmission networks outside the state. As for the altitudinous power bills, the state's attorney general has pledged that US $\$ 29$ million of the retail charges would be forgiven as part of a bankruptcy settlement with the power company involved (Burke, 2021). There does not seem to be wide interest among legislators for changing the law to prevent such a spike from happening again. Winter Storm Uri, it should be noted, was not without precedent. In 2011, a similar February cold snap froze Texas's power generators, triggering rolling blackouts for millions of customers (Hernandez et al., 2021). In 2014, a January freeze did the same (Schwartz et al., 2021).

\section{THE QUEENSLAND FLOODS}

Like Texas, the Australian state of Queensland has become known for its dramatic floods. The state's own website declares living with floods "a natural part of life" (Queensland Government, undated). Even by that standard, the torrents of 2010-11 were remarkable. Beginning in November 2010, a series of heavy rainstorms began rolling across the state over the course of several months. In the floods that ensued, thousands of residents were forced to flee their homes. Whole towns were submerged. Ultimately, the inundations-which also affected New South Wales and Victoria, though to a lesser degree-claimed 33 lives and destroyed billions of dollars of property (AIDR, undated).

The floods ruptured much of Queensland's electricity network, killing power even in areas with no physical damage (QFCI, 2012). Three hundred thousand customers lost power in two major towns, Ipswich and Brisbane. In the Lockyer Valley, one of the most seriously affected rural areas in Queensland, 5,000 people lost power (QFCI, 2012). In addition, the floods submerged open-pit coal mines and railway links, leading to global shortages of both coking coal (used in steel making) and thermal coal (used for power production), (Blas, 2011).
To assess and learn from these floods, the Australian government established the Queensland Floods Commission of Inquiry which released its report QFCI, 2012. The Report called for better mapping, updated flood-risk assessments, and more precise building codes. It also urged the state government to draft "model flood planning controls" for local councils to use in developing new planning schemes (QFCI, 2012, 12-3, 15-6, 21-2). Among other things, such controls would require that electrical substations be built so as to remain operational during floods of a particular magnitude based on a risk assessment that considered local needs and resources (QFCI, 2012, 246). While the Commission acknowledged the need to better understand climate change impacts like heavier rain and rising seas, it stopped short of recommending that such impacts be factored into future planning.

To support flood-management programs, the Australian government launched an authoritative national flood information and metadata database called the "Australian Flood Risk Information Portal (AFRIP).” The portal provides localized flood studies, hazard mapping, and management plans, including those relevant to grid resilience (Geoscience Australia, Web Portal, undated). There are currently 1,571 flood studies available on the portal, dating from 1909 to 2018, including 300 from Queensland. However, as of 2018, the portal contained "few studies ... that include climate change scenarios" (Coast Adapt, 2018).

In addition, Queensland's new State Planning Policy (SPP) addresses risk and resilience against natural hazards as one of several "state interests" that must be considered and applied in the development and amendment of local government planning instruments. Notably, the SPP counts the "projected impacts of climate change" among the risks associated with natural hazards (Operations Support, 2017; Queensland Government, 2017, 8, 51).

Queensland does not require electric utilities to have flood plans, though the state's two main power companiesEnergex and Ergon Energy Network-recently adopted a risk management plan that specifically addresses floods. The plan aims to "ensure the safety of the community in the event of damage or impact, manage and minimize the risk to network assets, improve response and maintain customer supply" (Ergon Energex Energy, 2019). Impressive in both detail and scope, the plan inventories existing assets, incorporates quantitative date from previous storms and floods, and is designed to integrate new observations. Still, it does not appear to directly factor in future climate impacts.

\section{OPPORTUNITIES FOR IMPROVING CLIMATE RESILIENCE}

In other writings, we have examined several important features of climate-resilience planning (Lyster and Verchick, 2018; Verchick, 2018). Here we focus on three features that should be better emphasized in the planning processes coming out of Texas and Queensland. That is, effective resilience measures should be (1) forward-looking, (2) "fit to function," and (3) capably financed. 


\section{Forward-Looking}

Forward-looking measures are ones that do not rely entirely on past impacts to inform future resilience standards. They instead incorporate science-based projections of future climate impacts like hotter temperatures, more precipitation, and rising seas.

The Texas Commission recommends using flood-plain designations provided by FEMA; but those designations do not incorporate climate projections. To its credit the Texas Commission urged local governments to add a margin of safety, or "freeboard," to projects within flood zones as a way to "future proof" them (EOS, 2018, 107). Yet there is no specification of how much freeboard is appropriate or what data should be used in making the determination.

The Queensland Commission recommended that the state or local government identify "flood plains" and suggested that facilities, including substations, be fortified for flooding or avoid the areas. However, it made no call for integrating future climate impacts into the maps. In response, Queensland adopted new mandatory construction standards for buildings, including those associated with electrical utilities. The law establishes a minimum freeboard standard of 300 millimeters (1 foot). Local councils may increase that amount if they want. There is no indication that climate data were used in selecting this standard.

For its part, Ergon Energy has since revised its flood level standard for the establishment of new bulk supply and zone substations. Its new standard requires zone substations to be built at or above the $0.5 \%$ AEP flood level (a so-called " 200 year event"). That is more protective than a $1 \%$ standard. But like the freeboard standards adopted in Queensland and some jurisdictions in Texas, the $0.5 \%$ AEP flood level does not appear to follow from climate projections.

Including climate data can make a big difference. In the wake of Hurricane Sandy (2012), Con Edison, the electric utility serving New York City, was required by state regulators to add 3 feet (1 meter) to its plans to fortify several existing substations to account for expected sea level rise and a margin of safety. After 2 years of more deliberate study (which included consultations with climate scientists as well as robust public hearings), the utility concluded that the design standards of those fortified substations could be exceeded in $<20$ years. It has since raised the standard for all new construction in floodplains. Accordingly, the existing fortified substations are likely to be again retrofitted in the coming decades or abandoned (Con Edison, 2021).

In the United States and Australia, few electric utilities take future climate impacts into account in any programmatic way. According to researchers at Columbia University's Sabin Center on Climate Change Law, those in the U.S. electricity sector frequently cite "limited data availability as a hindrance to climate resilience planning" (Webb et al., 2020, 10, Box 5). Power companies do need better information, which continues to improve. They also need better decision-making tools-ones that are adaptive, rather than static, and that can accommodate deep certainty. Traditionally, electric utilities have based their investment decisions on cost-benefit analysis-a poor fit for disaster planning of many kinds (Verchick, 2010, 195-222). Costbenefit models rely on quantified values for cost, harms avoided, and probabilities of loss. Where disasters are concernedparticularly those amplified by climate change-the degree of harm and probability of event are deeply uncertain. Cost of fortification may be the only value capable of plausible quantification, putting one in the cynic's position of knowing "the price of everything and the value of nothing" (Wilde, 1892/1995, 403).

More promising, we think, is a new wave of decisionmaking models based on flexible "policy pathways." Under this approach, utilities deploy no-or low-regrets resilience measures immediately and then set thresholds, or "trigger points," for taking actions that have greater trade-offs or that require more study. The trigger points "are based on pre-determined risk levels that, if left unaddressed, would result in severe impacts and potentially irreversible consequences." (Webb et al., 2020, 7-8). A trigger point, for instance, might be a calendar date indicating an era of statistically heightened storm risk or a finding that sea has risen $20 \%$ higher than had been predicted by that time. The goal is to put off long-lasting or irreversible decisions as long as possible in order to allow policy makers to learn as much as they can about the dimensions of the problem (Haasnoot et al., 2012; Kwakkel et al., 2016).

Another method, which relies on vast computational experiments, is called "robust decision making." Under this approach, pioneered by the RAND Corporation, researchers use powerful computers to subject policy options to a wide range of plausible, future scenarios in order to determine which option or set of options performs best over a range of varying circumstances (Lempert et al., 2013). The computational cost is high. In a hypothetical exercise involving a flood-prone river in the Netherlands, the evaluation of 14 policies over a range of scenarios required 70,000 computational experiments (Kwakkel et al., 2016, 179). Choosing the best decision-making approach obviously depends on the complexity of the task and the resources available.

It is a commonplace in climate change policy that the past is no longer a reliable measure for the future. Yet neither Texas nor Queensland has internalized this message in resilience planning. This situation is not only allowed, but arguably enabled by government decisions made at the federal level. While uncertainty in climate forecasts is sometimes cited as a reason for not considering future change, there are decision-making methods that can help policy makers protect people and property from future climate impacts even in the context of uncertainty. Such methods should be explored in Texas and Queensland.

\section{Fit to Function}

"Fit to function" is a phrase we use to describe the level of governance that is the best fit for the function that policy makers envision. The Texas and Queensland recovery prescriptions emphasize decision making and implementation at the local level. This tendency is sensible where climate resilience is concerned. Future climate impacts will be variable and contextual. Because of the urgency of the challenge and the lack of proven methods, experimentation-much of it occurring at the local level-will be key. Decentralization can also leverage local knowledge and 
take better account of community preferences (Camacho and Glicksman, 2019, 199).

There are some functions, however, that demand more centralized efforts. The development and distribution of scientific and economic research, for instance, would appear to benefit from economies of scale and the avoidance of redundancy. Financing expensive, protective infrastructure (whether machine-made or dependent on restored landscapes) is also an appropriate and necessary function of a federal or national government. The high cost of robust decision making, which demands high levels of computer power and expertise, also justifies a federal role. Because the design of infrastructure in one locality can significantly affect the welfare of citizens in other localities, there will often be a need for uniform standards, sometimes best implemented by a central authority (Camacho and Glicksman, 2019, 200-01). When the federal government is the primary funder, uniform standards also assure taxpayers that their money is being used prudently. Such assurances can help build public confidence in resilience efforts.

One example of such a standard is the U.S. Federal Flood Risk Management Standard, requiring federally funded infrastructure to be built with a higher margin of safety to account for future climate impacts like extreme floods and sea level rise (White House, 2021a). The standard, which was first issued by President Obama in 2015, was rescinded by President Trump in 2017 (before it could take full effect) and later reinstated by President Biden on his first day in office. Unfortunately, many federally funded infrastructure projects related to Hurricane Harvey had already been completed by the time the standard was reinstated.

While local autonomy is an important value (particularly where risk tolerance is involved), there is a fine line between delegating authority and abandoning responsibility. The Texas Report frequently reminds municipalities that their authority to select options will depend in part on their ability to pay. In summing up the section on city, rural, and industrial assets, for instance, the Texas report advises: "Each community must decide on its optimal portfolio of flood mitigation strategies, based on specific local characteristics and their ability to pursue them" (EOS, 2018, 122). The problem is that if the "local characteristics" include poverty or social marginalization, the prospect for meaningful choice is pretty narrow.

Under Australia's constitutional arrangements, the states and territories bear primary responsibility for flood risk management (Wenger, 2013, 65). A problem with assigning flood planning to local government is that local councils differ vastly in size and wealth. Thus, most of Australia's 537 local councils cannot afford to hire specialized flood management staff (Geneva Association, 2020, 29). The federal government has released a variety of tools, including the National Partnership Agreement for Natural Disaster Resilience, the National Climate Resilience and Adaptation Strategy; the National Disaster Risk Reduction Framework; and the National Land Use Planning Guidelines for Disaster Resilient Communities (Australian Government, 2015; Planning Institute Australia, 2015; Australian Government, 2018). They all refer to the need to build resilience to climate change but provide only high-level guidance to state, territory, and local governments-National informational tools include the
AFRIP and the yet-to-be-completed Electricity Sector Climate Information Project to develop high-quality climate data and simulations to support power system resilience (CSIRO).

Over the last 10 years, these and other efforts have led to a significant improvement in "the coverage, consistency and quality of flood risk mapping across Australia." (Geneva Association, 2020, 32). Even so, the "limited availability of funding has led to a patchy approach to assessment and understanding of flood risk across Australia" (Geneva Association, 2020, 32). In Queensland many at-risk communities still lack flood mapping (Geneva Association, 2020, 32).

Scaling government action to fit the desired function is a perpetual challenge. While there are good reasons to prefer decentralized approaches in preparing for climate change, centralized action should be strongly considered in situations demanding large resources or in situations prone to spill-over effects from one community to another. In the cases of Texas and Queensland, policymakers are right to emphasize local decisionmaking and community engagement. But the U.S. and Australian governments have an obligation to ensure that the states and local governments have the requisite scientific information (including flood maps informed by climate data), scientifically informed guidelines for setting protective standards, and broad access to technical assistance. In regions, like watersheds where the actions of one community can affect the welfare of other communities, federal authorities have a duty to make sure a minimum standard, informed by climate data, is in place to protect everyone. Further, federal and state authorities should ensure that a community's lack of resources or technical expertise does not unduly restrain it in making choices to protect the welfare and property of its residents. These considerations should be integrated into future resilience plans in Texas and Queensland.

It is important to remember that discussions about jurisdictional scale also take place in a context of constitutionally delegated powers. While not identical, the federal frameworks of the United States and Australia are similar in prominent ways. Both nations show a cultural and constitutional preference toward state-based land-use planning, while the federal governments exercise broad authority to tax and spend. The concept of "co-operative federalism," broadly defined as an arrangement in which the state and federal levels of government share regulatory powers, is also a mainstay of energy and environmental policy in both countries (Wiseman, 2018, 235-37; Kallies, 2021, 212). Of course, what is legally or politically possible in the United States or Australia may be off-limits in nations with more centralized or de-centralized governance structures. Such difference must be taken into account in applying the lessons learned in our case studies.

\section{Capably Financed}

As the previous discussion suggests, where broad-scale resilience is concerned, affordability is a major issue. Electricity infrastructure requires large up-front capital investments. The U.S. and Australian governments have each contributed many billions of dollars in recovering from these storms and floods, but serious funding gaps remain. The emphasis in both countries on "back end" recovery efforts over "front end" risk-reduction 
efforts complicates the problem (Geneva Association, 2020, 45). After all, smart investments in disaster prevention can repay themselves many times over (Bratspies et al., 2018, v).

In Texas, Houston has recently announced that a US\$1.4 billion shortfall could delay completion of its post-Harvey recovery efforts. The city had been hoping for a 2021 federal disaster grant which instead went to other parts of the country (Lazano, 2021; Oberg and Hatfield, 2021). According to the Associated Press, "[ $\mathrm{t}$ ]he projects in need of the most funding are in some of the area's poorest neighborhoods that have repeatedly flooded in recent decades" (Lazano, 2021). The state of Texas is charged with allocating US $\$ 4$ billion in federal funds to local communities, an insufficient amount that has led to much interregional squabbling, including allegations that Governor Abbot has inappropriately taken control of federal funds that were originally intended for Houston (Oberg and Hatfield, 2021). President Biden has promised to invest boldly in climate resilient infrastructure and a modernized grid (White House, 2021b; Worland, 2021). At the time of this writing, it remains to be seen if federal lawmakers will follow his lead.

In Australia, those calling for strong investment in grid modernization were disappointed by the release of the nation's 2021-22 budget (Hancock, 2021). Although the budget promises investment of more than AU\$15 billion investment in road, rail, and freight upgrades, investments in upgrading the grid were $<$ AU $\$ 50$ million (Commonwealth of Australia, 2012, 47).

The electricity markets in Texas and in Australia are light on regulation and heavy on consumer choice. Such marketfriendly approaches, in theory, maximize capital investment by allowing utilities to recover capital expenditures through higher rates. This was the idea behind "retail choice": if a utility knew it could charge a high price during an ice storm, it would have an incentive to make sure its equipment could operate in such conditions. While some argue that price spikes during winter storms were theoretically sufficient to encourage generators "to invest in protecting their equipment or building backup resources," this clearly did not happen (Gimon, 2021, 10). It seems that not even the utilities understood the probabilities well-enough to see that resilience investments would have paid off handsomely (Gimon, 2021, 11). Or maybe they correctly predicted that customer backlash would deprive them of such profiteering.

The Australian Energy Market Operator (AEMO), which regulates the nation's electricity market, also uses a "retail choice" model, but with a safety valve. AEMO caps the maximum spot price for retail electricity at AU\$15,000/MWh (about US\$11,126/MWh) with an automatic emergency cap of $\mathrm{AU} \$ 3,000 / \mathrm{MWh}$ (or $\$ \mathrm{US} 2,225 / \mathrm{MWh}$ ) that is triggered during sustained periods of high prices. (AER, 2019; AEMO, 2020, 15) Texas caps the spot price for electricity at US\$9,000 per MWh but without an emergency cap (Blumsack, 2021). But like the Texas model, Australia's market-friendly system is not enough on its own to attract the capital needed to build a sustainable grid. Generally speaking, Australia's "return on investment" formulas for establishing rates are more oriented toward efficiency and resilience than similar models in the United States. However, some argue there is still a gap between what universal resilience demands in up-front investment and what Australia's electric utilities are able to recover from customers (ENA, 2015, 7-8).

Investing in climate resilience makes good economic sense, but the up-front costs are high. Modernizing the electricity grid in the United States or in Australia will require tens of billions of dollars. The longer that governments defer these investments, the costlier these projects will be (and the more damage they will incur in the meantime). Current levels of government funding are insufficient to drive the change that is needed. Further, formulas used in regulating electricity rates may not adequately encourage utilities to invest in resilience measures or smart-grid technologies on the scale that is required. This is particularly true in the United States (Aas and O'Boyle, 2016). The U.S. and Australian governments should robustly fund grid resilience and modernization. Governments at the federal or state levels should revisit pricing formulas to encourage investments in resilience. These governments should also consider mandating use of certain resilience technologies as a way of driving modernization in the electricity sector.

\section{CONCLUSION}

Protecting the power grid from climate disaster is not a job that will be completed quickly or easily in any country. Strictly speaking, it will never be completed at all. Because climate change is a dynamic process and because our knowledge and technology will continually evolve, the pursuit of climate resilience is an ongoing task. What won't change, we believe, is the need for policies that are forward-looking, "fit to function," and capably financed. In protecting electricity infrastructure against the ravages of climate breakdown, Texas and Queensland are on the right track. Still, they can do more in each of those areas.

\section{DATA AVAILABILITY STATEMENT}

The original contributions presented in the study are included in the article/supplementary material, further inquiries can be directed to the corresponding author/s.

\section{AUTHOR CONTRIBUTIONS}

Both authors listed have made a substantial, direct and intellectual contribution to the work, and approved it for publication.

\section{FUNDING}

Australian Research Council Grant, DP 190103476, RL, Geegor Verbic, Daniel Farber, and RV, a legal framework for resilient electricity infrastructure in Australia.

\section{ACKNOWLEDGMENTS}

We would like to thank our fellow authors in this issue who participated in a workshop organized by our editors, Robin Craig and J. B. Ruhl. For their excellent research assistance, we thank Melia Cerrato, Stacie Osborne, and Rory McFadden. 


\section{REFERENCES}

Aas, D., and O'Boyle, M. (2016). You Get What You Pay for: Moving Toward Value in Utility Compensation. Part 2. San Francisco: Energy Innovation. Available online at: https://energyinnovation.org/wp-content/uploads/2020/01/you-getwhat-you-pay-for-2.pdf (accessed August 29, 2021).

AEMO (2020). Australian Energy Market Operator Fact Sheet: The National Electricity Market. Available online at: https://aemo.com.au/-/media/files/ electricity/nem/national-electricity-market-fact-sheet.pdf (accessed August 29, 2021).

AER (2019). Australian Energy Regulator. Electricity Spot Prices Above $\$ 5000 / M W h$. Available online at: https://www.aer.gov.au/system/files/Prices \%20above\%20\%245000MWh\%20-\%2025\%20January\%202019\%20\%28Vic \%20and\%20SA\%29.pdf (accessed August 29, 2021).

AIDR (undated). Australian Institute of Disaster Resilience. Queensland and Brisbane 2010/11 Floods. Available online at: https://knowledge.aidr.org.au/ resources/flood-queensland-2010-2011/

Amadeo, K. (2020). Hurricane Harvey Facts, Damage and Costs. The Balance. Available online at: https://www.thebalance.com/hurricane-harvey-factsdamage-costs-4150087 (accessed August 29, 2021).

Aronoff, K. (2021). Texas's Energy Crisis Is America's Future. New Republic. Available online at: https://newrepublic.com/article/161434/texas-energycrisis-green-new-deal (accessed August 29, 2021).

Australian Government (2015). National Climate Resilience and Adaptation Strategy.

Australian Government (2018). National Disaster Risk Reduction Framework.

Blas, J. (2011). Coal Prices Flare as Australian Floods Cut Supply. Financial Times. Available online at: https://www.ft.com/content/fa6441a8-1da8-11e0aa88-00144feab49a (accessed August 29, 2021).

Blumsack, S. (2021). What's Behind the $\$ 15,000$ Electricity Bills in Texas? The Conversation. Available online at https://theconversation.com/whats-behind15-000-electricity-bills-in-texas- 155822 (accessed August 29, 2021).

Bratspies, R., Burkett, M., Echeverria, J., Farber, D., Flatt, V., Flores, D., et al. (2018). From Surviving to Thriving: Equity in Disaster Planning and Recovery. Washington, DC: Center for Progressive Reform. Available online at: http://www.progressivereform.org/our-work/energy-environment/ surviving-thriving-main/ (accessed August 29, 2021).

Burke, M. (2021). \$29 Million of Electric Bills from Texas Winter Storm Will Be Forgiven, AG Says. NBC News. Available online at: https://www.nbcnews.com/ news/us-news/29-million- electric-bills-texas- winter-storm- will-be-forgivenn1261310 (accessed August 29, 2021).

Camacho, A. E., and Glicksman, R. L. (2019). Reorganizing Government: A Functional and Dimensional Framework. New York, NY: NYU Press. doi: $10.18574 / \mathrm{nyu} / 9781479829675.001 .0001$

Coast Adapt (2018). National Climate Change Adaptation Research Facility. Data and Visualisation Sources to Help Understand Flood and Erosion Risk. Available online at: https://coastadapt.com.au/how-to-pages/use-national-mappinghelp-understand-flood-and-erosion-risk (accessed August 29, 2021).

Commonwealth of Australia (2012). Budget 2021-22: Securing Australia's Recovery. Available online at: https://budget.gov.au/2021-22/content/download/glossy_ overview.pdf (accessed August 29, 2021).

Con Edison (2021). Climate Change Resilience and Adaptation. Available online at: https://www.coned.com/-/media/files/coned/documents/our-energyfuture/our-energy-projects/climate-change-resiliency-plan/climate-changeresilience-adaptation-2020.pdf (accessed August 29, 2021).

Cooper, R. (2021). What the Texas Blackouts Reveals About America's Climate Vulnerability. The Week. Available online at: https://theweek.com/articles/ 967062/what-texas-blackout-reveals-about-americas-climate-vulnerability (accessed August 29, 2021).

CSIRO. "Electricity Sector Climate Information Project." Climate Change in Australia, Commonwealth Science Industrial Research Organisation. Available online at: https://www.climatechangeinaustralia.gov.au/en/projects/ esci/ (accessed October 15, 2021).

Douglas, E., and Ramsey, R. (2021). No, Frozen Wind Turbines Aren't the Main Culprit for Texas' Power Outages. Texas Tribune. Available online at: https:// www.texastribune.org/2021/02/16/texas-wind-turbines-frozen/ (accessed August 29, 2021).
ENA (2015). Energy Networks Association. Future Network Cost Recovery and Depreciation: Regulatory and Policy Options. Available online at: https://www. energynetworks.com.au/resources/fact-sheets/future-network-cost-recoveryand-depreciation-regulatory-and-policy-options/ (accessed August 29, 2021).

EOS (2018). Eye of the Storm: Report of the Governor's Commission to Rebuild Texas. Available online at: https://disasterphilanthropy.org/notable-research/ eye-of-the-storm-report-of-the- governors-commission-to-rebuild-texas/ (accessed August 29, 2021).

Ergon and Energex Energy (2019). Flood Risk Management Plan 2019-20. Available online at: https://www.ergon.com.au/_data/assets/pdf_file/0018/ 800523/Flood-Risk-Management-Plan-2019-20.pdf (accessed August 29, 2021).

Fehling, D. (2013). Restoring Power: What Houston Learned from Ike. NPR. Available online at https://stateimpact.npr.org/texas/2013/09/12/restoringpower-what-houston-learned-from-ike/ (accessed August 29, 2021).

Geneva Association (2020). Flood Risk Management in Australia: Building Flood Resilience in a Changing Climate. Zurich: Geneva Association. Available online at: https://www.genevaassociation.org/research-topics/climate-change-andemerging-environmental-topics/flood-risk-management-australia (accessed August 29, 2021).

Geoscience Australia (Web Portal, undated). Australian Flood Risk Information Portal (Web Portal, undated). Available online at: https://afrip.ga.gov.au/floodstudy-web/\#/search (accessed August 29, 2021).

Gimon, E. (2021). Lessons from the Texas Big Freeze. Energy Innovation. Available online at: https://energyinnovation.org/wp-content/uploads/2021/05/Lessonsfrom-the-Texas-Big-Freeze.pdf (accessed August 29, 2021).

Haasnoot, M., Middelkoop, H., Offermans, A., van Beek, E., and van Deursen, W. P. A. (2012). Exploring pathways for sustainable water management in river deltas in a changing environment. Clim. Change 115, 795-819. doi: 10.1007/s10584-012-0444-2

Hancock, E. (2021). Australia's Federal Budget 'Missed Opportunity' to Prioritise Renewable Energy. PV-Tech. Available online at: https://www.pv-tech.org/ australias-federal-budget-missed-opportunity-to- prioritise-renewableenergy/ (accessed August 29, 2021).

Hernandez, A., Hoffman, K., Witte, G., and Gowen, A. (2021). As Millions Remain Without Power Amid More Snow and Ice, Blame and Questions Mount. Available online at: https://www.washingtonpost.com/national/ power-outages-winter-storm-texas/2021/02/17/1e848bce-7159-11eb-93bec10813e358a2_story.html (accessed August 29, 2021).

Intergovernmental Panel on Climate Change (IPCC) (2018). "Annex I: glossary," in Global Warming of $1.5^{\circ} \mathrm{C}$. An IPCC Special Report on the Impacts of Global Warming of $1.5^{\circ} \mathrm{C}$ Above Pre-Industrial Levels and Related Global Greenhouse Gas Emission Pathways in the Context of Strengthening the Global Response to the Threat of Climate Change, Sustainable Development, and Efforts to Eradicate Poverty, eds J. B. R. Matthews, Masson-Delmotte, V. P. Zhai, H.-O. Pörtner, D. Roberts, J. Skea, P.R. Shukla, A. Pirani, W. Moufouma-Okia, C. Péan, R. Pidcock, S. Connors, Y. Chen, X. Zhou, M. I. Gomis, E. Lonnoy, T. Maycock, M. Tignor, and T. Waterfield, 541-562.

Kallies, A. (2021). The Australian energy transition as a federalism challenge: (UN)cooperative energy federalism. Trans. Environ. Law 10, 211-35. doi: 10.1017/S204710252000045X

Kwakkel, J. H., Haasnoot, M., and Walker, W. E. (2016). Comparing robust decision-making and dynamic adaptive policy pathways for model-based decision support under deep uncertainty. Environ. Model. Softw. 86, 168-83. doi: 10.1016/j.envsoft.2016.09.017

Lazano, J. (2021). Houston Area Flood Control Effort Facing \$1.4B Shortfall. New York, NY: Associated Press.

Lempert, R. J., Popper, S. W., Groves, D. G., Kalra, N., Fischbach, J. R., Bankes, S. C., et al. (2013). Making Good Decisions Without Predictions: Robust Decision Making for Planning Under Deep Uncertainty. Santa Monica, CA: RAND Corporation.

Lott, M. (2017). Hurricane Harvey was a Major Test for the Texas Power Grid. Scientific American. Available online at: https://blogs.scientificamerican.com/ plugged-in/hurricane-harvey-was-a-major-test-for-the-texas-power-grid/ (accessed August 29, 2021).

Lyster, R., and Verchick, R. R. M. (2018). "Protecting the power grid from climate disasters" in Research Handbook on Climate Disaster Law: Barriers and 
Opportunities, eds R. Lyster, and R. R. M. Verchick (Cheltenham: Edward Elgar Publishing), 424. doi: 10.4337/9781786430038

Oberg, T., and Hatfield, M. (2021). ABC13. Harris County and Houston Left out of $\$ 1$ billion in Flood Mitigation Aid. Available online at: https://abc13. com/hurricane-harvey-flood-aid-harris-county-houston/10669614/ (accessed August 29, 2021).

Operations Support (2017). "Queensland Government department of natural, resources, and mines," in Guide for Flood Studies and Mapping in Queensland.

Planning Institute Australia (2015). National Land Use Planning Guidelines for Disaster Resilient Communities.

QFCI (2012). Queensland Floods Commission of Inquiry. Final Report. Available online at: http://www.floodcommission.qld.gov.au/publications/final-report/ (accessed August 29, 2021).

Queensland Government (undated). Get Ready Queensland. Available online at: https://www.getready.qld.gov.au/understand-your-risk/types-naturaldisasters/flood. undated (accessed August 29, 2021).

Queensland Government (2017). Queensland State Planning Policy.

Roberts, D. (2021). Lessons from the Texas Mess Volts. Available online at: https:// www.volts.wtf/p/lessons-from-the-texas-mess (accessed August 29, 2021).

Sandoval, E., Rojas, R., and Waller, A. (2021). Death Toll from Texas' Winter Storm Rises Sharply to 111 NY. Times. Available online at: https://www.nytimes. com/2021/03/25/us/texas-winter-storm-death-toll.html (accessed August 29, 2021).

Schwartz, J., Collier, K., and Davila, V. (2021). Power Companies Get Exactly What They Want. Texas Tribune and ProPublica. Available online at: https://www. texastribune.org/2021/02/22/texas-power-grid-extreme-weather/ (accessed August 29, 2021).

St. John, J. (2015). How CenterPoint's Integrated Smart Grid Is Paying Off. GTM. Available online at: https://www.greentechmedia.com/articles/read/ how-centerpoints-integrated-smart-grid-is-paying-off (accessed August 29, 2021).

TLBO (2017). Turning the Lights Back on After Hurricane Harvey. Power Technology. Available online at: https://www.power-technology.com/features/ turning-lights-back-hurricane-harvey/ (accessed August 29, 2021).

Verchick, R. R. M. (2010). Facing Catastrophe: Environmental Action in a Post-Katrina World. Cambridge, MA: Harvard University Press. doi: $10.2139 /$ ssrn. 1633518

Verchick, R. R. M. (2018). "Planning for climate change disaster" in Research Handbook on Climate Disaster Law: Barriers and Opportunities, eds R. Lyster, and R. R. M. Verchick (Cheltenham: Edward Elgar Publishing), 416.
Webb, R. M., Panfil, M., and Ladin, S. (2020). Climate Risk in the Electricity Sector: Legal Obligations to Advance Climate Resilience Planning by Electric Utilities. Columbia Law School and Environmental Defense Fund.

Wenger, C. (2013). Climate Change Adaptation and Floods: Australia's Institutional Arrangements. National Climate Change Adaptation Research Facility.

White House (2021a). Executive Order: Executive Order on Protecting Public Health and the Environment and Restoring Science to Tackle the Climate Crisis. Exec. Order No. 13990, 86 Fed. Reg. 7037.

White House (2021b). Fact Sheet: President Biden Announces Support for the Bipartisan Infrastructure Framework. Available online at: https://www. whitehouse.gov/briefing-room/statements-releases/2021/06/24/fact-sheetpresident-biden-announces-support-for-the-bipartisan-infrastructureframework/ (accessed August 29, 2021).

Wilde, O. (1892/1995). Lady Windermere's Fan. London; Oxford: Elkin Mathews and John Lane at the Bodley Head. Reprint, ed Peter Raby; Oxford Paperbacks, 45.

Wiseman, H. (2018). Delegation and dysfunction. Yale J. Regul. 35, 233-299.

Worland, J. (2021). To See How Biden's Infrastructure Plan Will Address Climate Change, Look at the Details. Time. Available online at: https://time.com/ 5951505/biden-climate-change-infrastructure/ (accessed August 29, 2021).

Conflict of Interest: The authors declare that the research was conducted in the absence of any commercial or financial relationships that could be construed as a potential conflict of interest.

Publisher's Note: All claims expressed in this article are solely those of the authors and do not necessarily represent those of their affiliated organizations, or those of the publisher, the editors and the reviewers. Any product that may be evaluated in this article, or claim that may be made by its manufacturer, is not guaranteed or endorsed by the publisher.

Copyright $\odot 2021$ Verchick and Lyster. This is an open-access article distributed under the terms of the Creative Commons Attribution License (CC BY). The use, distribution or reproduction in other forums is permitted, provided the original author(s) and the copyright owner(s) are credited and that the original publication in this journal is cited, in accordance with accepted academic practice. No use, distribution or reproduction is permitted which does not comply with these terms. 